\title{
EVALUATION OF FOUR PERENNIAL RYEGRASS CULTIVARS IN NEW ZEALAND
}

G.A. KERR
Yates Research

Abstract

Four perennial ryegrass (Lolium perenne) cultivars have been evaluated at a range of summer-autumn drought prone sites in New Zealand. Evaluation has been carried out at seven replicated large plot grazing trials sown with clover and one trial without clover evaluated under mowing.

The cultivars with a low level of Iolium endophyte (Acremonium loliae) infection, Ruanui and the majority of Nui lines, have displayed poor persistence. In summer-autumn dry areas, sowing seed with a high endophyte content appears the only alternative to obtain a persistent perennial ryegrass pasture.

Within the high endophyte cultivars (Yatsyn 1 . Ellett and some Nui lines), Yatsyn 1 has performed consistently well in terms of long term yielding ability, indicating persistence.

Keywords: Lolium perenne, endophyte (Acremonium loliae), annual yields, seasonal yields, Ruanui, Nui, Ellett, Yatsyn 1.

\section{INTRODUCTION}

Perennial ryegrass will always have its place in the farming industry. Its ability to withstand heavy grazing and pugging gives flexibility to a management system, and its long term yielding ability reduces resowing costs.

As a large seed company centred in New Zealand, our work has been targeted towards a market demand. Perennial ryegrass seed volume dressed annually is around eight and a half thousand tonnes (NZ Official Yearbook 1985), with much of this tonnage being retailed in the drier east coast regions of New Zealand (Yates Company Report). As a consequence ryegrass cultivar evaluation sites have been positioned throughout New Zealand in generally summer-autumn drought prone east coast regions.

\section{METHOD}

Eight trials have been run in a range of sites in New Zealand to agronomically assess Grasslands Ruanui and Nui along with Yates Ellett and Yatsyn 1 perennial ryegrass cultivars (Table 1).

Table 1: List of Trial sites and districts including the period of trial and soil type at each site.

\begin{tabular}{llll}
\hline Trial Site & District & Trial Period & Soil Type \\
\cline { 2 - 4 } Glenbrook & South Auckland & 1981.83 & Patumahoe clay loam \\
Takapau & Hawkes Say & since 1983 & Matapiro silt loam \\
Halkett & Central Canterbury & 1981.83 & Waimakarir shallow sandy loam \\
Porters Pass & Central Canterbury & since 1982 & Lismore silt loam \\
Aylesbury & Central Canterbury & since 1983 & Lismore silt loam \\
Lyndhurst & Mid Canterbury & $1982-84$ & Lyndhurst silt loam \\
Lyndhurst & Mid Canterbury & since 1984 & Lyndhurst silt loam \\
Hinds & Mid Canterbury & since 1982 & Reconstituted border-dyke soil. Irrigated.
\end{tabular}

The trials have been sown in randomised complete block designs and, with the exception of the Lyndhurst 1984 trial, have had the same method of assessement. All cultivars have been sown in 4 replications in plots 12 by 12 metres in size, at $20 \mathrm{~kg} / \mathrm{ha}$ of ryegrass and $3 \mathrm{~kg} / \mathrm{ha}$ of Huia white clover. 
Yield assessments with subsampling for dry matter determinations and herbage dissections have been carried out, on average, eight times each year when the sward height of the best cultivar has reached $7-10 \mathrm{~cm}$. Each plot was assessed for yield by mowing a $10 \mathrm{~m} \times 50 \mathrm{~cm}$ strip, using a 3-bladed reel mower adjusted to a cutting height of $1.5-2 \mathrm{~cm}$. To prevent resampling of any area in a particular year, the mowing strip was shifted across the plots by 1 metre at each consecutive cut.

Large numbers of stock are used after mowing to prevent selectivity of grazing while exposing the trials to the animal effect and effectively pre-trimming the trial to a grazing height of less than $1.5 \mathrm{~cm}$.

The Lyndhurst 1984 trial has been planted without clover in a randomised complete block design with 12 replicates. The plots are $10 \mathrm{~m} \times 2 \mathrm{~m}$ in size with a strip eight square metres being mown for yield assessment. The entire plot is then pretrimmed using a rotary mower.

The trials have had 2 equal applications of fertiliser a year with an annual application of $40 \mathrm{~kg} / \mathrm{ha}$ nitrogen, $33 \mathrm{~kg} / \mathrm{ha}$ phosphate and potassium and $3 \mathrm{~kg} / \mathrm{ha}$ sulphur.

Since 1983 the level of infection with lolium endophyte (Acremonium Ioliae) has been assessed using the lactophenol cotton blue staining procedure. Thirty leaf sheath samples per cultivar were assessed for presence of endophyte (Neill 1941) at the Aylesbury trial after emergence (Table 2). These are the same seed lines that were sown at Takapau. For the 1984 Lyndhurst trial, a random sample of 20 seeds were tested for endophyte (adaptation of technique from Williams et a/. 1984) prior to sowing.

Table 2: Endophyte levels of cultivars.

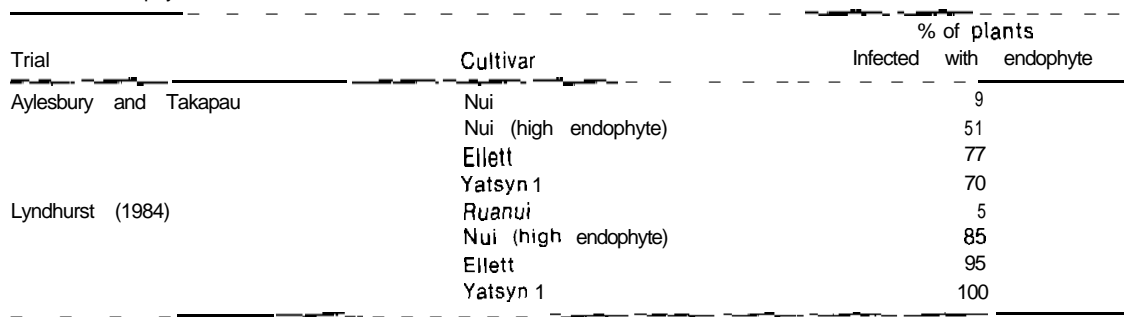

The ryegrass yield results have been divided on an annual and seasonal basis, with seasons defined as

Spring - September, October, November

Summer — December, January, February

Autumn - March, April, May

Winter - June, July, August

In cases where the trial has been run for 3 years or more, the seasonal yield results do not include the first years data, minimising establishment variability.

Means tests on annual and seasonal data has been carried out using Duncans new multiple range test, at the 5 percent significance level. Where no statistically significant differences occurred, no Duncan's test is indicated.

\section{RESULTS AND DISCUSSION}

Evaluation of perennial ryegrass cultivars has been targeted to supply information to the largest market demand within New Zealand, namely summer and autumn drought prone farmers. The main requirement of a cultivar is for long term high yield. The sale of perennial ryegrasses far exceeds that of annual or short rotation ryegrasses (NZ Official Yearbook 1985) so it is essential to adequately assess perenniafity or persistence in these environments. 
Table 3. Mean ryegrass yields presented annually (relative to Ellett $=100$ )

\begin{tabular}{|c|c|c|c|c|c|}
\hline Site & Cultivar & Year 1 & Year 2 & Year 3 & Year 4 \\
\hline \multirow[t]{4}{*}{ Glenbrook } & Yatsyn 1 & 96 & $107 a$ & & \\
\hline & Ellett & 100 & $100 a$ & & \\
\hline & Nui & 104 & $82 b$ & & \\
\hline & $\mathrm{kgDM} / \mathrm{ha}$ Ellett & 4944 & 5076 & & \\
\hline \multirow[t]{4}{*}{ Takapau } & Yatsyn 1 & 96 & 97 & 108 & \\
\hline & Ellett & 100 & 100 & 100 & \\
\hline & Nui* & 92 & 97 & 101 & \\
\hline & $\mathrm{kgDM} / \mathrm{ha}$ Ellett & 6006 & 6895 & 8810 & \\
\hline \multirow[t]{4}{*}{ Halkett } & Yatsyn 1 & 103 & $115 a$ & & \\
\hline & Ellett & 100 & $100 a b$ & & \\
\hline & Nui & 108 & $88 \mathrm{~b}$ & & \\
\hline & kgDM/ha Ellett & 2052 & 3834 & & \\
\hline \multirow[t]{5}{*}{ Porters Pass } & Yatsyn 1 & 107 & $10 \%$ & $95 a$ & $105 a$ \\
\hline & Ellett & 100 & $100 a b$ & 100.3 & $100 a$ \\
\hline & Nui & 105 & 93ab & $72 b$ & $77 \mathrm{~b}$ \\
\hline & Ruanui & 102 & $84 \mathrm{~b}$ & $65 b$ & $66 \mathrm{~b}$ \\
\hline & $\mathrm{kgDM} / \mathrm{ha}$ Ellett & 2811 & 7175 & 6576 & 9312 \\
\hline \multirow[t]{5}{*}{ Aylesbury } & Yatsyn 1 (70) & 99 & 106 & $111 a$ & \\
\hline & Ellett (77) & 100 & 100 & $100 a$ & \\
\hline & $\mathrm{Nui}^{*}(51)$ & 104 & 100 & $96 a$ & \\
\hline & Nui (9) & 89 & 86 & $57 a$ & \\
\hline & kgDMiha Ellett & 5803 & 5384 & 3977 & \\
\hline \multirow[t]{5}{*}{ Lyndhurst (1982) } & Yatsyn 1 & $111 a$ & $104 a$ & & \\
\hline & Ellett & $100 a$ & $100 \mathrm{a}$ & & \\
\hline & Nui & $72 \mathrm{~b}$ & $81 b$ & & \\
\hline & Ruanui & $69 b$ & $68 b$ & & \\
\hline & $\mathrm{kgDM} / \mathrm{ha}$ Ellett & 1965 & 8428 & & \\
\hline \multirow[t]{5}{*}{ Lyndhurst (1984) } & Yatsyn 1 (100) & $106 a$ & 105 & & \\
\hline & Ellett (95) & $100 a$ & 100 & & \\
\hline & Nui* (85) & $96 a$ & 99 & & \\
\hline & Ruanui (5) & $55 b$ & & & \\
\hline & $\mathrm{kgDM} / \mathrm{ha}$ Ellett & 4543 & 5552 & & \\
\hline \multirow[t]{5}{*}{ Hinds } & Yatsyn 1 & $106 a$ & $106 a$ & $114 a$ & $124 a$ \\
\hline & Ellett & $100 a b$ & $100 a$ & $100 a$ & $100 b$ \\
\hline & Nui & $79 c$ & $88 a b$ & $69 b$ & $59 \mathrm{c}$ \\
\hline & Ruanui & $92 b$ & $77 \mathrm{~b}$ & $68 b$ & $52 d$ \\
\hline & kgDM/ha Ellett & 4695 & 9268 & 5216 & 3796 \\
\hline
\end{tabular}

"Nui high endophyte (Figures in brackets from Table 2)

A good estimate of persistence may be obtained by considering cultivar yields from the third year after seeding (Table 3 ).

Major differences in persistence between the perennial ryegrass cultivars can be attributed to the presence or absence of lolium endophyte (Acremonium loliae). The cultivars Yatsyn 1 and Ellett consistently contained a high level of endophyte, Ruanui a low level and Nui a variable level (Table 2). This agrees with the results obtained from endophyte testing of commercial Ellett, Ruanui and Nui ryegrass lines (Scott 1983). In the trials, the perennial ryegrasses with a high level of infection with the endophyte fungus have significantly outyielded the cultivars containing a low level of endophyte at all sites except Halkett, where Ellett and low endophyte Nui were no different (Table 3). Lolium endophyte has been found responsible for increased yield and persistence in other trials (Barker et al. 1986; Prestidge et al. 1985). This has been attributed to endophyte conferring resistance to a range of 
insects (Gaynor et al. 1986). Within the high endophyte cultivars, no differences in long term yielding ability were significant, except at Hinds where in the fourth year Yatsyn 1 outyielded Ellett (Table 3).

Relative differences between cultivars in seasonal yields were not consistent over all sites (Table 4). However the main differences were between cultivars with different endophyte levels and occurred in the summer and autumn periods, often carrying over into the following seasons. At this time of the year pasture supply seldom meets livestock requirements, so extra herbage production can be fully utilised. Within high endophyte cultivars, seasonal yield differences were generally not significant, however, Yatsyn 1 demonstrated superior autumn yield over Ellett at Lyndhurst (1984) and Hinds, and over Nui (high endophyte) at Lyndhurst (1984), and superior winter yield over Ellett at Halkett (Table 4).

Table 4: Mean pryeqrass yields presented seasonally (relative to Ellett $=100$ )

\begin{tabular}{|c|c|c|c|c|c|}
\hline Site & Cultivar & Spring & Summer & Autumn & Winter \\
\hline \multirow{4}{*}{ Glenbrook } & Yatsyn 1 & 94 & $117 a$ & 102 & 102 \\
\hline & Ellett & 100 & $100 a$ & 100 & 100 \\
\hline & Nui & 91 & $78 b$ & 95 & 99 \\
\hline & kgDM/ha Ellett & 1371 & 824 & 1175 & 1263 \\
\hline \multirow[t]{4}{*}{ Takapau } & Yatsyn 1 & 95 & 108 & 110 & 107 \\
\hline & Ellett & 100 & 100 & 100 & 100 \\
\hline & Nui* & 93 & 97 & 103 & 111 \\
\hline & kgDM/ha Ellett & 2854 & 2084 & 1205 & 1463 \\
\hline \multirow[t]{4}{*}{ Halkett } & Yatsyn 1 & 115 & 90 & 105 & 143a \\
\hline & Ellett & 100 & 100 & 100 & $100 \mathrm{~b}$ \\
\hline & Nui & 108 & 81 & 85 & $103 \mathrm{~b}$ \\
\hline & kgDM/ha Ellett & 1874 & 683 & 656 & 276 \\
\hline \multirow[t]{5}{*}{ Porters Pass } & Yatsyn 1 & $103 a$ & $99 a$ & $103 a$ & $102 a$ \\
\hline & Ellett & $100 \mathrm{a}$ & $100 \mathrm{a}$ & $100 a$ & $100 \mathrm{a}$ \\
\hline & Nui & $85 p$ & $74 b$ & $84 b$ & $78 b$ \\
\hline & Ruanui & $79 b$ & $60 \mathrm{~b}$ & $78 \mathrm{~b}$ & $69 b$ \\
\hline & kgDM/ha Ellett & 2303 & 2182 & 953 & 1585 \\
\hline \multirow[t]{5}{*}{ Aylesbury } & Yatsyn 1 & 103 & $113 a$ & $104 a$ & $106 a$ \\
\hline & Ellett & 100 & $100 a$ & $100 a$ & $100 a b$ \\
\hline & Nui ${ }^{*}$ & 93 & $96 a$ & $105 a$ & $94 a b$ \\
\hline & Nui & 62 & $57 \mathrm{~b}$ & $63 b$ & $85 b$ \\
\hline & kgDM/ha Ellett & 1926 & 1101 & 842 & 671 \\
\hline \multirow[t]{5}{*}{ Lyndhurst (1982) } & Yatsyn 1 & 99 & $97 a$ & 125 & 139 \\
\hline & Ellett & 100 & $100 a$ & 100 & 100 \\
\hline & Nui & 93 & $65 b$ & 78 & 68 \\
\hline & Ruanui & 81 & $52 \mathrm{C}$ & 70 & 65 \\
\hline & kgDM/ha Ellett & 1726 & 2069 & 1312 & 122 \\
\hline \multirow[t]{5}{*}{ Lyndhurst (1984) } & Yatsyn 1 & $98 a$ & $108 a$ & $113 a$ & $114 a$ \\
\hline & Ellett & $100 a$ & $100 a$ & $100 \mathrm{~b}$ & $100 \mathrm{a}$ \\
\hline & Nui' & $96 a$ & $97 a$ & $99 b$ & $125 a$ \\
\hline & Ruanui & $68 \mathrm{~b}$ & $61 \mathrm{~b}$ & $48 \mathrm{C}$ & $76 b$ \\
\hline & kgDM/ha Ellett & 2164 & 1353 & 1369 & 321 \\
\hline \multirow[t]{5}{*}{ Hinds } & Yatsyn 1 & $105 a$ & $118 \mathrm{a}$ & $128 \mathrm{a}$ & $97 a b$ \\
\hline & Ellett & $100 a b$ & $100 a$ & $100 \mathrm{~b}$ & $100 \mathrm{a}$ \\
\hline & Nui & $75 c$ & $58 \mathrm{~b}$ & $98 \mathrm{~b}$ & $68 c$ \\
\hline & Ruanui & $81 \mathrm{bc}$ & $50 \mathrm{~b}$ & $68 \mathrm{c}$ & 71 bc \\
\hline & kgDM/ha Ellett & 3104 & 1326 & 1175 & 382 \\
\hline
\end{tabular}


White clover yields in the trials were small and usually inversely related to ryegrass yields, With more vigorous perennial ryegrasses, this has highlighted the importance to obtain spring control of pastures, to stop shading of clover, and in the long term the need to develop more competitive clovers.

To the sheep farmer the advantages of endophyte in perennial ryegrass are not as clear cut. Lolium endophyte has been implicated in ryegrass staggers and reduced spring liveweight gains in sheep and lambs (Fletcher 1983). However in spite of outbreaks of ryegrass staggers, farmlets of high endophyte ryegrass pastures gave higher per hectare animal production because of their higher herbage yield (Fletcher 1986). The better persistence of the high endophyte pastures would likely lead to a larger advantage in per hectare animal production in the following years.

\section{CONCLUSIONS}

In summer-autumn dry areas, sowing perennial ryegrass seed with a high endophyte content appears the only alternative to obtain a persistent ryegrass pasture.

The trial results indicate the perennial yielding ability of Yatsyn 1 ryegrass and its suitability for use in the summer-autumn dry regions in which these trials were carried out.

\section{References}

Barker G.M., Prestidge R.A., Pottinger R.P. 1966. Strategies for Argentine stem weevil control: Effects of drought and endophyte. Proceedings NZ Grassland Association 47: 107.114.

Fletcher L.R. 1963. Effects of presence of Iolium endophyte on growth rates of weaned lambs, growing on to hoggets, on various ryegrasses. Proceedings NZ Grassland Association 44: 237-239.

Fletcher L.R. 1966. Lolium endophyte and sheep performance on perennial ryegrass cultivars. Proceedings NZ Grassland Association 47: 99.105.

Gaynor D.L., Rowan D.D. 1966. Insect resistance, animal toxicity and endophyte-infected grass. Proceedings NZ Grasslands Association 47: 115120

Neill J.C. 1941. The endophytes of Lolium and Festuca. NZ Journal of Science and Technology Vol 23. No 4A: 185.193.

Prestidge R.A., Di Menna M.E., Van Der Zijpp S., Baden D 1965. Ryegrass content, Acremonium endophyte and Argentine stem weevil in pastures in the Volcanic Plateau. Proceedings 38th NZ Weed and Pest Control Conference. 41.44.

Scott D.J 1963. Lolium endophyte levels in commercial perennial ryegrass seed lines. Proceedings NZ Grassland Association 44: 254.256 .

Williams M.J., Backman P.A., Clark E.M., White J.F. 1964 Seed treatments for control of the tall fescue endophyte, Acremomonium coenophialum. Plant Diseases Vof 1. No 68: 49-52. 